\title{
A reflection on the relationship between performance management and training in the South African public service
}

Author:

P. Harry Munzhedzi ${ }^{1}$

\section{Affiliation:}

${ }^{1}$ Department of Public and Development Administration, University of Venda, South Africa

\section{Corresponding author:} Harry Munzhedzi, harry.munzhedzi@univen. ac.za

\section{Dates:}

Received: 16 Sept. 2016 Accepted: 29 Aug. 2017 Published: 22 Nov. 2017

How to cite this article: Munzhedzi, P.H. (2017). A reflection on the relationship between performance management and training in the South African public service. SA Journal of Human Resource Management/SA Tydskrif vir Menslikehulpbronbestuur, 15(0), a864. https://doi. org/10.4102/sajhrm. v15i0.864

\section{Copyright:}

(C) 2017. The Authors. Licensee: AOSIS. This work is licensed under the Creative Commons Attribution License.
Orientation: Performance management plays a pivotal role in the realisation of many facets of public administration, including service delivery, good governance and organisational productivity through setting of performance targets and regular assessments of performance. In search of improved quality and productivity in the public service, the South African government introduced several legislative and policy interventions, including but not limited to the Public Service Act, 1994 (Proclamation 103 of 1994), Public Service Regulations of 2001 and the White Paper on Transforming Public Service Delivery of 1997.

Research purpose: The main thrust of this conceptual paper was to explore the relationship between performance management and training in the South African public service.

Motivation for the study: The lack of sufficient literature on the relationship between performance management and training. To also prove that the two are inseparably linked, meaning that one cannot exist without the other.

Research design, approach and method: This article, which is conceptual in nature, reviewed existing literature on performance management and training in the public service extensively so as to arrive at a definitive conclusion.

Main findings: The article contends that as much as training underpins the process of performance management, training is also fortified by performance management. Precisely, there cannot be performance management without training and vice versa.

Practical/managerial implications: As much as training is imperative in the management of performance in the public service, such training must be need-based and it must be underpinned by performance management through identification of skills gap in the assessment of performance.

Contribution: It is proposed that to enhance the knowledge, capacity, effectiveness and efficiency of the public service performance, needs-based training that seeks to close the skills gap, is developed and adequately implemented.

\section{Introduction}

Public Service Regulations of 1999 provide that both present and prospective public servants ought to be trained so as to achieve an efficient, effective, non-partisan and career-oriented public service, which is 'broadly representative' of the South African community in terms of section 195 of the Constitution of the Republic of South Africa, 1996 (Du Toit, Knipe, Van Niekerk, Van der Waldt \& Dolve, 2002). Such Regulations also provide that programmes to educate, train and develop public servants should be demand-driven and that they must seek to address the identified challenges of lack of skills and capacity among others. That is, the public service should at all cost avoid trainings that are not aligned with the skills gap identified. However, proper measures of identifying this lack of skills and capacity must be designed so as to address the existing challenges. In the context of South Africa, the Department of Higher Education and Training (2016) compiled a report on the skills supply and demand in government departments and reported that there is a dire shortage of skills in the country, needless to say that only $20 \%$ have a tertiary qualification, $32 \%$ have completed secondary education and close to half of the workforce do not have a grade 12 certificate. This lack of requisite skills has a negative impact on the provision of basic services.

Note: This article is partially based on the author's thesis of the degree of Master of Administration in Public Administration at the University of South Africa, South Africa, with supervisor Prof. K.G. Phago and joint supervisor Ms V.P.P. Disoloane, received October 2011, available here: http://uir.unisa.ac.za/bitstream/handle/10500/5537/thesis_munzhedzi_p.pdf 
Kroukamp (2011, p. 25) is of the view that for government departments to improve the relevance of their skills development plans, it is critically important to strengthen, through a coordinated approach with all role players, the manner in which skills assessments and provision are done. Unfortunately, the skills audit as well as the trainings provided to public servants, often through National School of Government (NSG), are often not aligned (Mello, 2015; Munzhedzi, 2011). Performance management also has a positive contribution towards training management, including that of assisting public service managers to identify and pinpoint performance gaps and weaknesses.

The purpose of this article is to explore the relationship between performance management and training in the South African public service. The article commences by providing a coherent conceptualisation of the notions of performance management and training with the view of establishing a commonality in their understanding, at least in the context of this article. The article further argues that the relationship between the two is inevitable in that training often ensues after the lack of skills and capacity has been identified through the performance management process. It is for this reason that Munzhedzi (2011) propounds that, performance of both individual employees and by extension the whole organisation is enhanced through training, which should be focused on the identified challenging areas. For adequate understanding, training and performance management are conceptualised before the exploration is advanced.

\section{Conceptualising performance management and training in the public service}

According to Armstrong (1995, p. 429), performance management is a means of getting better results from an institution, teams and individuals by understanding and managing performance within an agreed framework of planned goals, standards and competence requirements. Cardy and Dobbins (1994, p. 2), on the other hand, define performance management as a formal and systematic process by means of which the job-relevant strength and weakness of employees are identified, measured, recorded and developed. Although performance management may sound as if it has the same meaning as a performance management system (PMS), they are different. A PMS is an authoritative framework for managing employee performance that includes a policy framework as well as a framework relating to all aspects and elements in the performance cycle, including performance planning and agreement, performance monitoring, review and control, performance appraisal and moderating and managing the outcome of appraisals (Mello, 2015; Munzhedzi \& Phago, 2014; Simeka Management Consulting, 2004). Munzhedzi (2011, p. 14) also posits that PMS gives guidelines on how everything to do with performance management is to be done, from goal setting and deciding how to measure accomplishments to providing regular assessments.
A PMS is also a process that begins by translating overall institutional objectives into clear individual objectives that will be set as targets for individual employees on a quarterly or annual basis (Amos, Ristow, Ristow \& Pearse, 2008, p. 286). The performance target of individual employees also sets the agenda for supervisors and individual employees regarding the monitoring and reviewing of performance. It is in those set performance targets and requirements that the satisfactory or non-satisfactory performance of employees will be determined. After such determinations, good performance may be rewarded and poor performance may be improved through appropriate improvement measures. Good performance refers to a performance where an employee achieves the set performance targets and bad performance refers to a performance where an employee consistently fails to achieve the set performance targets (Aguinis, 2009; Mello, 2015; Viedge, 2011). In essence, performance management is the means applied to harness available resources to improve performance, productivity and service delivery in the context of the public service. It therefore means that performance management focuses not only on the management of the workforce but also on the effective, efficient and economic use of requisite resources including but not limited to financial and material resources. Most important is that the said resources may be properly managed by a trained and competent workforce.

Institutions all over the world are often applying wideranging strategies to stay ahead of global competition insofar as training and development is concerned. In order to stay ahead of the said competition, Kroukamp (2011, p. 24) posits that institutions should continuously invest in the skills and knowledge capital of the workforce through inter alia training. However, it can be argued that training is not a miracle cure by which all management and administrative challenges can be unravelled. It is one of the pivotal human resource development practices that may be used by an institution to capacitate and improve the productivity of their workforce (Erasmus, Loedolff, Mda \& Nel, 2008, p. 45). Training basically refers to a learning opportunity that is provided in order to improve individual as well as organisational performance (Vukovic, Zavrsnik, Rodic \& Miglic, 2008, p. 655), and it assists government to develop some kind of necessary capacities of public servants and promote institutional change. The said capacitation contributes towards equipping these public servants with the necessary knowledge, skills and competencies to achieve their set performance targets effectively and efficiently. Like performance management being a paramount factor in training and development, training plays a crucial role in the performance management process. Of paramount importance, as far as Kroukamp (2011) is concerned, is that training is one mechanism which, if properly utilised, could bring about a visible change in the performance of the public service. The ensuing discussion focuses on the different training models applicable in enhancing the skills gap that would have been identified through the performance management process further supporting Kroukamp's (2011) argument that performance and training are inextricably interconnected to 
each other. Mello (2015) correctly notes that for good management performance to take place, a proper functioning PMS is necessary. That is, a proper PMS is a prerequisite for proper performance management.

\section{Various training models to enhance performance in the public service}

There are different models that are used to impart knowledge and skills in the public service officials, namely, orientation training, e-learning, sensitivity training, team building, case study, coaching and job rotation (Du Toit et al., 2002). Department of Higher Education and Training (2016) indicates that there is a mismatch between the kind of skills and competencies that are in demand versus what the education sector is currently supplying. Department of Higher Education and Training (2016) further notes that skills that lack in the main are those in the scare skills professions, including but not limited to health sciences, accounting and engineering. These lacking skills are the ones that are needed the most, but they are in short supply. To a certain extent, this may affect the overall organisational performance because there is generally lack of skills in the South African public service including at the local sphere of government. The different models of training that the government may consider in addressing the lack of skills and capacity are discussed below.

\section{Orientation training}

While new employees may have requisite academic qualifications, they often lack necessary familiarity with specific circumstances and skills of the new job (National School of Government, 2015; Underwood, 2002). It is paramount that each and every new public service employee is orientated so that he or she may be familiarised with the new work environment including all the technicalities required. It is therefore a prerequisite for all new employees to be oriented (Public Service Commission, 2014). The performance of an employee who has not been oriented is likely to be affected in that the employee does not have a clear picture of the organisational objectives and his or her part in a bigger puzzle. It is critical that an employee understands or be oriented of the bigger picture in the organisation so that he or she may be able to link his or her performance targets with the organisational annual plan, strategic plan, vision and mission and the National Development Plan (NDP) in the case of government in its entirety (Minnaar, 2010). It is therefore crucial to ensure that new employees are oriented so as to augment their performance and the management of it thereof.

\section{Sensitivity training}

Sensitivity training refers to training that focuses on improving interpersonal relations (Du Toit et al., 2002, p. 181; Mello, 2013; Underwood, 2002). In this case, it is assumed that emotional problems contribute negatively in the job performance of employees. Van der Weisthuizen and Wessels
(2013, p. 334) purport that the main aim of sensitivity training is to sensitise or make employees aware of their own behaviour and how such behaviour affects fellow co-workers. This effect may either be positive or negative. It is for this reason that most public service institutions have got a specialised unit called 'Employees' Wellness Programme', which basically focuses on the wellness of employees. It does counselling for employees who either have marital, drug or alcohol problems particularly because all these 'not workrelated' problems directly or indirectly do affect the performance of the employees in the public service. It is therefore safe to say that work-related skills alone do not matter as far as performance management is concerned.

\section{Team building}

Team building is often about new or even old employees of the department or the municipality getting to know each other in a not-so-formal environment. According to Van der Weisthuizen and Wessels (2013, p. 334), team building addresses information about how the groups work together, what problems exist and what norms are followed and sought. Activities associated with team building are goal setting, development of interpersonal relations and clarification of roles and responsibilities (Du Toit et al., 2002; Knipe, 2002). After the interactions, the facilitator assists the group to understand the feedback and also develop the action plans so as to improve the processes and increase trust and openness. The more employees interact, the more they get to know each other and the more they know and trust each other, the more they are likely to perform well as a group and the more they perform well as a group, the more the organisation is likely to be productive, which ultimately results in improved service delivery.

\section{Simulation}

Simulation refers to a method whereby a particular work is done in the presence of the employees or trainees, thereafter, those employees will have to replicate it to show that they have learned. The main objective of simulation is to show that employees may be able to replicate that which they have learned (De Cenzo \& Robbins, 1994, p. 269; Knipe, 2002; Van der Westhuizen \& Wessels, 2013, p. 335). Some of these works is done or shown to a group but individual employees have to demonstrate an element of understanding.

\section{Case study}

To demonstrate an understanding, employees or trainees may be provided with a written description of a particular actual or hypothetical case. In such cases, employees or trainees are required to analyse the case, identify and discuss the identified problem and finally suggest possible solutions. De Cenzo and Robbins (1994, p. 269) posit that the case study method seeks to show trainees that there is no easy solution to organisational problems, that there may be various but equally valid solutions and that case studies assist trainees with problem-solving skills. 


\section{Coaching}

Coaching basically refers to a case where experienced managers guide, mentor and supervise the work of those who are less experienced (Fisher, Schoenfelt \& Shaw, 1993, p. 39). The advantage of coaching is that trainees receive performance feedback as and when they engage in their daily tasks and activities. With coaching, the mentor or the coach is more hands-on regarding guidance and supervision unlike the other methods of training (De Cenzo \& Robbins, 1994). It is also one of the best forms of identifying underperformance and good performance. It is through this identification of the state of performance that mentors or managers are able to develop improvement or corrective plans (Erasmus, Swanepoel, Schenk, Van der Westhuizen \& Wessels, 2005, p. 337). It is through coaching that underperformance is identified and addressed as and when it is identified, meaning that the coach does not have to wait until the end of the quarter or the financial year. However, other scholars including Fisher, Schoenfelt and Shaw (1993, p. 39), are of the opinion that the disadvantage is that the trainee may adopt the manager or mentor's way of doing things, which may at times not necessarily be the best there is. This article argues that coaching is one of the best method of training and performance management ingredient compared to other training models discussed.

\section{Job rotation}

Job rotation refers to a method of moving employees from one job assignment to another within the same organisation and possibly in the same salary or job level (Van der Westhuizen \& Wessels, 2013, p. 336). This is done to give employees a broader perspective of the mission, vision and objectives of the organisation. In a way, job rotation encourages generalists instead of job specialists in that organisational employees obtain overall perspective of the organisation. In short, you can not only be able to manage organisational human resource but also you must be able to develop strategic plan, draft budget and project expenditure, train the unskilled, analyse expenditure patterns and so on. It also becomes easier to cover for an employee who is on leave or replace an employee who has just resigned because other employees are generalists as well and they can fill in the gap in no time. It therefore means that there is a greater benefit in job benefit in that individual employees are exposed to broader organisational objectives and operations (Decenzo \& Robbins, 1994, p. 272) than specialising or having one focus area. It is also a common purpose that more employees may appreciate being exposed to other greater opportunities than to do routine and boring work. However, a disadvantage may be that other employees have become more like specialists in their specific field of work. This may mean that they may not want to be rotated for the fact that they are already a specialist and learning a new field may prove to be difficult.

Nevertheless, job rotation is a positive contribution not only to public service training but also to performance management. An individual employee may be moved from one unit to another for having under-performed or lack of skills on their previous division or unit. The movement is often done with an anticipation that the identified employee will perform better in the new unit because they have a particular skill, qualification or desire that may assist him or her perform better in the new unit.

\section{E-learning}

E-learning refers to a learning approach whereby learning resources, including booklets and software materials, are provided electronically to the targeted group of public service employees (More, 2002; Van der Westhuizen \& Wessels, 2013, p. 336). These learning materials could also be a video, audio, slideshow or web-based training services provided through online portal. The advantage of this form of training is that to an established organisation, this may be cost-effective in that the institution does not have to hire an external service provider or a physical being to conduct training. The Information Technology (IT) devices may be able to provide such training with a click of a button. It is important to note that the introduction of technology must be accompanied by technological illiteracy of employees as well as availability of relevant equipment (Mathevula \& Uwizeyimana, 2014). E-learning may be a valuable tool of conveying needed information to public officials. While the same IT devices may be valuable for training purposes, they may be used to capture performance management information as well. Such information may include submission of performance instruments, underperformers, good performers and those who are in need of training. It further justifies the fact that the relationship between performance management and training is inevitable.

However, E-learning may prove to be a challenge in a country like South Africa where computer illiteracy is widespread (Mathevula \& Uwizeyimana, 2014). It means that government in its entirety may have to strengthen its base and capacity regarding its effort to train its officials.

The foregoing paragraphs highlighted various types of training model that may be used to impart knowledge and capacity in the public service officials particularly for skills gap identified through the performance management process. However, each of these different models has got its own pros and cons. Nevertheless, each one of these models may contribute positively to the development of capacity in the South African public service, particularly if others may be applied simultaneous, such as coaching and job rotation. Munzhedzi (2011, p. 34) posits that it is imperative for the municipality (or the public service in this case) as provided for by section 45 of the Municipal Systems Act, 2000 (Act 32 of 2000), to conduct a performance audit in order to find out their strengths and weaknesses. In essence, these models are not only enablers of training insofar as capacitation is concerned but they complete the performance management process in that underperformers are assisted through the very same models discussed. The ensuing paragraphs discuss 
different role players and the specific role they play in the performance management process.

\section{Role players in the performance management system}

There are several role players in the process of managing performance in the public service. These role players include the Public Service Commission, the Department of Public Service and Administration (DPSA), NSG, trade unions and employees. These role players are discussed in detail below.

\section{Public Service Commission}

The Public Service Commission (PSC) was established in terms of section 196 of the 1996 Constitution as a chapter 10 institution that promotes values and principles set out in section 195, throughout the public service (Republic of South Africa, 1996). Some functions of the Commission are to propose measures to ensure effective and efficient performance within the public service. The Commission also has a watchdog role to play in that it investigates, monitors and evaluates human resource practices of the public services (Erasmus et al., 2005, p. 9; Mello, 2013; PSC, 2014). The performance agreements of Provincial Heads of Department and National Directors General are coordinated by the Office of the PSC. The implementation of human resource policies are monitored and evaluated at the PSC. Upon completion of its processes of investigations, inspections, monitoring and evaluations, the Commission publishes its findings as public reports. Some of the reports published include a report on the payment of performance incentives (bonuses or pay progression) to Heads of Departments without annual performance evaluations conducted in 2008 and a report on the analysis of Performance Agreements as an effective performance management tool conducted in 2009. A PSC has further responsibility to advise national and provincial organs of state regarding personnel practices relating to recruitment, appointment, transfer, discharge and career management (Mello, 2015; PSC, 2014). It is the responsibility of the PSC to ensure that policies such as the PMS are properly implemented in the public service and advise where necessary.

\section{Department of Public Service and Administration}

According to the White Paper on Human Resource Management in the Public Service of 1997, the DPSA focuses in terms of human resources solely on the public service. The key responsibilities for the DPSA include developing human resource policies, getting support for such policies from organised labour at national level, ensuring practicality of application for the policies and ensuring that human resource policies are aligned with other transformation initiatives (Department of Public Service and Administration, 1997; Erasmus et al., 2005, p. 35). The DPSA also has to give support service to national departments and provincial administration regarding the implementation of human resource policies and development of capacity to implement the developed policies and programmes. Even the first PMS policy framework was initiated by the DPSA in 1999 to serve as a guide to national and provincial departments in developing their own departmental policies. All public service institutions have to align their policies with DPSA's framework. Individual performance targets have to be aligned to the departmental goals and objectives in order to enhance the overall performance of the department (Banfield \& Kay, 2008, p. 310). However, the policy of a specific department must be in line with the DPSA's policy framework on a PMS and each department's policy must be relevant to its own needs and circumstances.

\section{National of School of Government}

NSG seeks to contribute towards establishing a capable, professional and responsive public service that is committed to and has institutionalised the values and policies of a Developmental State (National School of Government, 2015, p. 10). The NSG was officially launched in 2013 , which was a replacement to the Public Administration Leadership and Management Academy (PALAMA) and this was established in 2008 as a replacement for the South African Management Development Institute with the mandate of facilitating training provision to public servants (Kroukamp, 2011, p. 26). NSG is constituted as a Schedule 1 department by the Public Service Act, 1994 (Proclamation 103 of 1994) as amended by the Public Service Act, 1999 (Act 5 of 1999). NSG is headed by a Director-General who reports to the Minister of Public Service and Administration. NSG, as the public sector training academy, has a central role to play in building the capacity of the public service to perform effectively and efficiently (PALAMA, 2010, p. 3). PALAMA trains and develops public service employees in order to enable them to improve their performances, which will then contribute to the improvement of public service delivery.

However, there are major challenges facing NSG in the fulfilment of its mandate of contributing to the development of a high-performing public service by capacitating public servants (PALAMA 2010, p. 4). One of the challenges includes the uncoordinated way in which public service training is conducted. PALAMA aims to ensure that public servants have all the necessary skills including technical, leadership and financial. According to the Public Service Amendment Act, 2007 (Act 30 of 2007), there shall be a training institution listed as a national department, which shall provide training or cause such training to be provided (Republic of South Africa, 2007). Lack of understanding of a PMS in the public service should be addressed by NSG through relevant training programmes.

\section{Trade unions}

The Labour Relation Act, 1995 (Act 66 of 1995) defines a union as an association of employees whose primary purpose is to regulate the relations between employees and employers including associations that represent employers. A union that wishes to continuously be in touch with issues affecting its members in any institution will ensure that it has a shop 
steward at every level possible (Republic of South Africa, 1995; Bendix, 2001, p. 167). Unions have to ensure that the management of an institution recognises their shop stewards because they (shop stewards) play a pivotal role in the workplace in all matters that affect their membership. It must also be highlighted that public sector employment is highly unionised with majority of its employees affiliated to one union or the other (Kroukamp, 2011, p. 22). Congress of South African Trade Unions constitutes majority of the public service employees. From the development of a PMS policy to the facilitation of the process, trade unions play a role in representing the interests of their members. The unfair treatment of employees with regard to payment of performance bonuses or subjective assessment of employees' performance often leads to trade unions being in endless confrontations with management. The shop steward has to ensure that the relationship between the union and its members is maintained and promoted (Bendix, 2001, p. 168). When employees have not received performance bonuses at the end of the financial year, they often lodge complaints with a trade union against their employer. Trade unions also intervene when their members allege that they have been treated unfairly as far as the PMS is concerned.

\section{Capacity versus training and performance management}

There is an inevitable relationship between the human capacity of public service employees together with their training and performance management. Capacity refers to the availability of and access to concrete or tangible resources (human, financial, material or technological) and having the knowledge to implement policies and the delivery of public services (Koma, 2010, p. 114). Capacity may also refer to the intangible resources such as commitment to, and leadership for, the implementation of policies and delivery of public services (Brynard \& De Coning, 1999, p. 2006). It may also be associated with potential to translate policy objectives into practical and tangible outcomes, which are often the needs of the community as captured during the development of manifestos by political parties. It is generally well accepted that some policies of government are very good and well thought of. However, the question of capacities of public functionaries always come into play. No matter how good the public policies are, lack of capacity often results in limited or no implementation of those policies at all. In a way, capacity makes a huge difference between a good and a bad public policy.

Lack of capacity to translate the said policies is often identified through performance management processes, namely, quarterly and annual assessments often by supervisors. Through the said assessments which are done on a regular basis, supervisors are able to pinpoint and identify lack of skills and capacity, underperformance and good performance by officials. However, it must also be noted that underperformance is not always as a result of lack of skills and capacity. It may also be because of pure laziness. It is also the view of Ivancevich, Konopaske and Matteson (2011, p. 209) that employees should not be required to perform responsibilities that exceed their current skill or knowledge level if they have not received training. More efficient structures, procedures and criteria of training have to be established with the Public Service Sector Education and Training Authority taking the lead role in this respect (Munzhedzi, 2011, p. 30). However, the process does not end at the regular assessments of performance but at closing the gap between the lack of skills and capacity and achieving the set performance objectives. Training plays a vital role in the implementation of a PMS in any public service institution. A PMS that is not linked to training is not likely to succeed in the inculcation of maximum performance. Lack of training in an institution can result in underutilised abilities (Byars \& Rue, 2006, p. 222).

To be precise, an inevitable relationship between skills and capacity, training and performance management exists. It often starts with identification of lack of skills and capacity through performance management and proceeds with training of those with limited skills and capacity. It must be noted that one may only identify weaknesses and strength if you assess that particular performance. It is then that training may be effected to enhance skills and capacity of those found to be lacking. However, Munzhedzi (2011, p. 78) correctly postulates that in government most of the training that is done is not aligned to the skills gap or challenge. Nevertheless, the Public Service Commission (2010, p. 8) is emphatic on the fact that the functioning of the machinery of government needs to be strengthened through the development of appropriate skills to ensure that institutional capacity is built and services can be delivered optimally.

\section{Conclusion}

In essence, the South African public service is essentially responsible for bringing government policy into practice. Basically, the public service is there to implement government policies and realise the policy objectives into practical operations. However, implementation of government policies may not be such a smooth process if the implementing body, namely, the public service does not have capacity to implement. It is the duty of government to ensure that underperformance and lack of skill and capacity are pinpointed and identified so that they may be addressed through appropriate measures. Kroukamp (2011) correctly posits that the numerous training programmes developed to address the skills gap in the field of public administration and management, be it the formal curricula, work-integrated learning to improve the challenges regarding bridging the gap between theory and practice or Memoranda of Understanding between different role players to transfer skills for improved service delivery, should adequately reflect and address ongoing challenges seeking to improve productivity or service delivery in the case of the public service. To this end, orientation, sensitivity training, e-learning, job rotation, coaching, case study, team building and simulation are some of the measures that may be used to 
address skills and capacity gap in the public service so as to ultimately improve performance of employees. However, performance management as a system that is used to identify performance gaps must also be beefed-up so that it may be able to do so effectively. The implication of this analogy is that, if skills gaps are not correctly identified through PMS, the training programmes developed may incorrectly solve the wrong problem and the service provision is going to suffer. Wessels (2006, p. 1505) also concurs that if the wrong problem has been diagnosed or if the wrong skill shortage has been identified, then wrong or inappropriate solutions may be proposed. As a result, employees will be trained on skills they do not need, meaning the wrong problem will be addressed. Munzhedzi (2011, p. 78) postulated that training could play a paramount role in the improvement of performance and productivity in government. However, there must be a proper skills audit and training based on proper and regular assessments. In order to avoid unnecessary expenditure on training, the impact (of these trainings) should be seen through the performance of an employee. Nevertheless, the significance and the unavoidable link between the two variables, namely, performance management and training cannot be overemphasised because they complement each other, and that one cannot be successfully be undertaken without the other.

\section{Acknowledgements Competing interests}

The author declares that he has no financial or personal relationships that may have inappropriately influenced him in writing this article.

\section{References}

Aguinis, H. (2009). Performance management. Upper Saddle River, NJ: Pearson Prentice Hall.

Amos, T.L., Ristow, A., Ristow, L., \& Pearse, N.J. (2008). Human resource management (3rd edn.). Cape Town: Juta \& Co Ltd.

Armstrong, M. (1995). A handbook of personnel management practice. London: Kegan Page.

Banfield, P., \& Kay, R. (2008). Introduction to human resources management. New York: Oxford University Press.

Bendix, S. (2001). Industrial relations in South Africa. Lansdowne: Juta.

Brynard, P., \& De Coning, C. (1999). Policy implementation. In F. Cloete, H. Wissink, \& C. De Coning (eds.), Improving public policy, (pp. 196-203). Pretoria: Van Schaik Publishers.

Byars, L.L., \& Rue, L.W. (2006). Human resource management. New York: McGraw-Hill.

Cardy, R., \& Dobbins, G. (1994). Performance appraisal: Alternative perspectives. Cincinnati, $\mathrm{OH}$ : South-Western College Publishing.

De Cenzo, D.A., \& Robbins, S.P. (1994). Human resource management: Concepts and practice. Toronto: Wiley.

Department of Higher Education and Training. (2016). Skills supply and demand in South Africa. Pretoria: DHET.

Department of Public Service and Administration. (1997). White paper on human resource management in the public service. Pretoria: Government Printer.
Du Toit, D., Knipe, A., Van Niekerk, D., Van der Waldt, G., \& Dolve, M. (2002). Service excellence in governance. Sandown: Heinemann.

Erasmus, B., Swanepoel, B., Schenk, H., Van der Westhuizen, E.J., \& Wessels, J.S. (2005). South African human resource management for the public sector. Cape Town: Juta.

Erasmus, B.J., Loedolff, P.V.Z., Mda, T., \& Nel, P.S. (2008). Managing training and development in South Africa (4th ed.). Cape Town: Oxford Southern Africa.

Fisher, C.D., Schoenfelt, L.F., \& Shaw, J.B. (1993). Human resource management. Boston, MA: Houghton Mifflin.

Ivancevich, J.M., Konopaske, R., \& Matteson, M.T. (2011). Organisational behavior and management. New York: McGraw-Hill.

Knipe, A. (2002). Project human resources management. In A. Knipe, G. Van der Waldt, D. Van Niekerk, D. Burger, \& K. Nell (eds.), Project management for success. Sandown: Heinemann.

Koma, S.B. (2010). The state of local government in South Africa: Issues, trends and options. Journal of Public Administration, 45(1.1), 111-120.

Kroukamp, H. (2011). Efficient and responsive public services: Are departments of Public Administration and Management at universities playing their rightful role? Administratio Publica, 19(1), 20-32.

Mathevula, M.D., \& Uwizeyimana, D.E. (2014). The challenges facing the integration of ICT in teaching and learning activities in South African rural secondary schools. Mediterranean Journal of Social Sciences, 5(20), 1087-1097. https://doi. org/10.5901/mjss.2014.v5n20p1087

Mello, D.M. (2013). Managing human capital in the public sector. Pretoria: Van Schaik.

Mello, D.M. (2015). Performance management and development system in the South African public service: A critical review. Journal of Public Administration, 50(3.1), 688-699.

Minnaar, F. (2010). Strategic and performance management in the public sector Pretoria: Van Schaik.

More, S. (2002, February 21-23). E-learning: A new tool of education in YCMOU. Paper presented at the 15th Annual Conference of the Asian Association Open Universities (AAOU), New Delhi, India.

Munzhedzi, P.H. (2011). Performance management system and improved productivity: A case of the department of local government and housing in the Limpopo Province. Unpublished Masters dissertation. Pretoria: University of South Africa.

Munzhedzi, P.H., \& Phago, K. (2014). Performance management system quandary in the public service: A case of the Limpopo province, South Africa. Journal of Public Administration, 49(4), 1083-1099.

National School of Government. (2015). Strategic plan 2015/16-2019/20. Pretoria: NSG.

Public Administration Leadership and Management Academy (PALAMA). (2010). Public administration leadership and management academy's strategic plan for 2010-2013. Pretoria: PALAMA.

Public Service Commission (PSC). (2010). State of the public service report. Pretoria: Government Printers.

Public Service Commission (PSC). (2014). Public service commission annual report 2013/2014. Pretoria: Government Printers.

Republic of South Africa. (1995). Labour Relation Act, 1995 (Act 66 of 1995). Pretoria: Government Printer.

Republic of South Africa. (1996). Constitution of the Republic of South Africa, 1996 Pretoria: Government Printer.

Republic of South Africa. (2007). Public Service Amendment Act, 2007 (Act 30 of 2007). Pretoria: Government Printer.

Simeka Management Consulting. (2004). Performance management system information manual. Polokwane: Limpopo Provincial Government.

Underwood, W.L. (2002). Cultural awareness sensitivity training. Unpublished Masters dissertation. Charleston, WV: Marshall University.

Van der Westhuizen, E., \& Wessels, J.S. (2013). South African human resource management for the public sector ( 2 nd ed.). Cape Town: Juta.

Viedge, C. (2011). Performance management. In A. Werner (ed.), Organisational behaviour: A contemporary South African perspective (3rd ed.), (pp. 135-158). Pretoria: van Schaik.

Vukovic, G., Zavrsnik, B., Rodic, B., \& Miglic, G. (2008). The training of civil servants in the Slovene state administration: Issues in introducing training evaluation. International Review of Administrative Sciences, 74(4), 653-676. https://doi. org/10.1177/0020852308098473

Wessels, J.S. (2006). The challenge of knowledge production by researchers in public administration, a South African perspective. South African Journal of Higher Education, 19(Special edition), 1499-1515. 